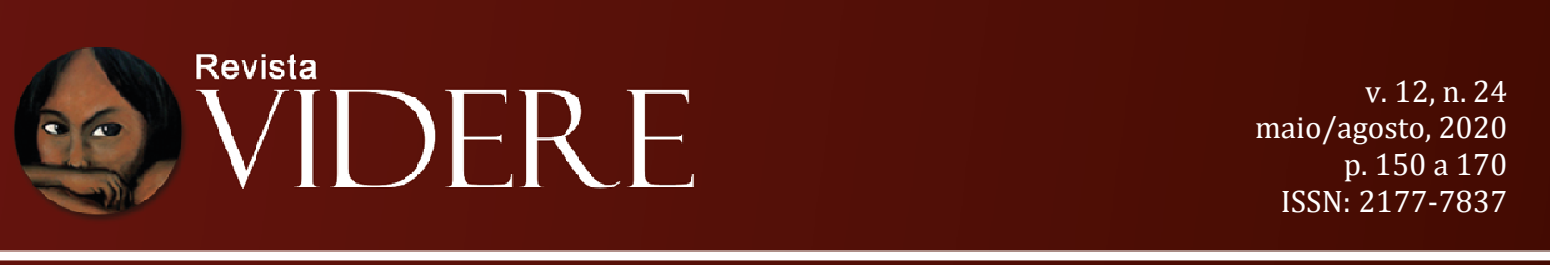

\title{
A VIOLÊNCIA INSTITUCIONAL E SIMBÓLICA COMO ANTINOMIA DO DIREITO: PELA NÃO-VIOLÊNCIA COMO PRECEITO JURÍDICO FUNDAMENTAL
}

\author{
INSTITUTIONAL AND SYMBOLIC VIOLENCE AS ANTINOMY OF LAW: FOR \\ NON-VIOLENCE AS FUNDAMENTAL LEGAL PRECEITO
}

\author{
Andre Luiz Valim Vieira \\ Doutor em Ciências Sociais (Relações Internacionais) (UNESP), Brasil \\ Bacharel e Mestre em Direito (UNESP), Brasil \\ E-mail: and.vieira@yahoo.com.br \\ OrcID: https://orcid.org/0000-0003-1052-6594
}

\begin{abstract}
RESUMO: O presente artigo tem por objetivo o estudo da violência materializada através dos atos de guerras entre as nações e das ações do Estado - em âmbito nacional - enquanto detentor do monopólio da violência pública e institucional ou dita como legítima e autorizada pela norma jurídica. Pretendemos assim analisar os tipos e formas de violência elencadas pelos principais teóricos políticos para enfim compreender como a não-violência toma forma e fundamentação e tende a se apresentar como uma alternativa social, jurídica e legitimamente possível como fator de enfrentamento da violência estatal. Com fundamentos teóricos e metodológicos em Hannah Arendt, Celso Lafer, Jean-Marie Muller, e Gene Sharp almejamos contrapor a violência versus uma não-violência ativa e socialmente organizada.
\end{abstract}

PALAVRAS-CHAVE: Violência estatal. Guerras e violência. Não-violência.

ABSTRACT: This article aims to study the violence materialized through the acts of wars between nations and the actions of the State - at the national level - as a monopoly on public and institutional violence or said to be legitimate and authorized by the legal norm. Thus, we intend to analyze the types and forms of violence listed by the main political theorists in order to finally understand how nonviolence takes shape and foundations and tends to present itself as a social, legal and legitimately possible alternative as a factor in confronting state violence. With theoretical and methodological foundations in Hannah Arendt, Celso Lafer, Jean-Marie Muller, and Gene Sharp we aim to counter violence versus active and socially organized nonviolence.

KEYWORDS: State violence. Wars and violence. Non-violence.

\section{Introdução}

O presente artigo é resultado das pesquisas científicas desenvolvidas junto ao Doutorado do Programa de Pós-graduação em Ciências Sociais (Relações Internacionais) da 
Universidade Estadual Paulista (Câmpus de Marília / SP). Propomos um estudo acerca das formas de violência realizadas pelo Estado modernamente: violência institucional - que pode ser física ou psicológica - e a violência simbólica. Na mesma medida, propomos a nãoviolência, a partir dos conceitos e fundamentações teóricas construídas pelos mais destacados pensadores da não-violência no Século XX, como uma forma de enfrentamento e resistência às violências estatais e institucionais.

Para isso iniciamos a compreensão do tema da violência e como esta é apropriada pelo Estado institucionalizado, seja ele autocrático ou democrático, como ferramenta de controle social e de imposição das vontades políticas dos dominantes: tanto internamente na existência de uma nação como no sistema internacional. Em meio a essa tormenta da violência surge então a proposta da não-violência como uma alternativa possível e real. Um novo caminho para as pessoa, a sociedade e as instituições.

Assim, com fundamento em Norberto Bobbio e somando-se ainda o pensamento de Hannah Arendt, Celso Lafer, Johan Galtung, Jean-Marie Muller, entre outros; procuraremos apresentar a não-violência como uma teorização política e humanitária que, no cenário atual, melhor consegue proteger os direitos humanos e fundamentais dos sujeitos em conflito, especialmente quando os confrontos são contra o Estado e é a violência utilizada como meio por seus agentes e órgãos institucionais de controle e repressão.

\section{Sobre a violência}

$\mathrm{O}$ século $\mathrm{XX}$ foi, em grande medida, um século onde a violência predominou. Os conflitos entre as nações ganharam novas conotações e se expandiram tanto em dimensão espacial quanto em poder bélico e destrutivo. Muitas foram as barbáries e os genocídios. Inúmeros conflitos ceifaram a vida de muitos militares e de muitos jovens e em igual medida de populações e grupos civis como alvos - diretos ou indiretos - desses enfrentamentos.

Apenas para citar alguns: entre 1904 e 1905 houve a Guerra Russo-Japonesa, uma disputa pelos territórios da Coreia e da Península de Liaodong. De 1912 a 1913 a Guerra dos Balcãs, na península balcânica. A Primeira Guerra Mundial (1914-1918) demonstrou a indústria da guerra e o avanço das armas de extermínio e da tecnologia como ferramentas militares. Após, temos ainda a ocorrência de diversos conflitos locais como a Guerra Civil Russa (1918-1922) e a Guerra Civil Espanhola (1936-1939).

Com a Segunda Guerra Mundial (1939-1945) a imagem da guerra ganhou novos contornos se ampliando o número de combatentes, de vítimas e de armas de destruição com capacidade beligerantes nunca vista. Em todas essas disputas violência, medo, sofrimento, 
domínio são armas tão poderosas quanto os mísseis, ogivas e demais instrumentos destrutivos.

Ao analisar a trajetória dos conflitos bélicos no Século XX, Hannah Arendt nos alerta que: "O progresso técnico dos instrumentos da violência alcançou agora o ponto onde objetivo político algum poderia corresponder ao seu potencial de destruição ou justificar o seu emprego real em conflitos armados" (ARENDT, 1985, p. 01). E, inversamente do que se antes se esperava ao fim de uma guerra e ao emprego da violência, após a segunda grande guerra, não houvera uma praz razoável e durável. Sucederem-se diversas outras guerras, seja na explosão do uso da violência seja em conflitos internos dos Estados e na dinâmica internacional.

Por essas razões reitera a pensadora judia:

Hoje em dia todas essas antigas verdades sobre o relacionamento entre a guerra e a política ou sobre a violência e o poder tornaram-se inaplicáveis. À $2^{\mathrm{a}}$ Guerra Mundial não se seguiu a paz, mas sim uma guerra fria e o estabelecimento do complexo militar-industrial (ARENDT, 1985, p. 08).

Embora a segunda grande guerra tenha sido um período determinante para o pensamento pacifista e a ampliação das doutrinas da não violência não é de se negar sua ocorrência como incapaz de deter conflitos seguintes: Guerra do Vietnã (1964 - 1963), Guerra do Yomkipur (1973), Guerra Irã-Iraque (1980-1988), Guerra do Golfo (1990-1991), Guerra do Kosovo (1996-1999); entre outras. Não como compreender o breve século XX sem ela, a guerra (HOBSBAWM, 1995, p. 30). Ela esteve presente nos principais fatos da história recente.

Para Domenico Losurdo o "[...] século XX é marcado por guerras e revoluções que prometem, em modalidades diferentes, a realização da paz perpétua, ou seja, é marcado por violências cuja motivação é erradicar de uma vez por todas o flagelo da violência" (LOSURDO, 2012, p. 14). O marco comum de qualquer conflito bélico é a violência. A matriz principal de toda guerra é a violência. Sejam as guerras entre as nações, a guerra ao terror; ou, seja a guerra às drogas (HARI, 2018) ou a guerra às organizações criminosas, outrossim, qualquer outra denominação de guerra interna.

Algumas disputas e conflitos envolvem interesses sobre domínios territoriais; outras sobre poder econômico, sobre hegemonia política. O traço comum e intrínseco a todas elas: a violência. Guerra significa, inexoravelmente, em violência, seja ela nacional ou internacional; interna e externamente. 
No limiar de um novo século havia esperanças de que esse novo período da história não fosse marcado pela violência e pelas guerras. Nascia assim o século XXI como uma promessa de exercício das propostas de paz antes teorizadas e defendidas nas décadas finais da última centúria. Não demorou muito para a violência voltar a surgir e com ela as consequências de terror, medo, sofrimento. Os acontecimentos do onze de setembro trouxeram novamente cenas em que violência foi o motor dos acontecimentos. E, depois novas guerras, novas lutas, novos conflitos.

A violência, todavia, não se restringe somente aos conflitos entre as nações, impérios e entre Estados soberanos. A violência é uma força destrutiva que pode se vestir de diversos tipos, cores, nuances, formas e contra diversas pessoas. Atinge diversas vítimas: imigrantes, pobres, mulheres, crianças, negros, idosos, deficientes, cidadãos; enfim, a todos. Nas palavras de Jean-Marie Muller (2007, P. 31): “A violência atinte sempre o rosto que ela deforma com o reflexo do sofrimento; toda violência é uma desfiguração. A violência fere e deixa marcas profundas na humanidade de quem a sofre".

Utiliza-se de muitos meios de relações sociais para a manutenção de sua existência: violência no trânsito, violência religiosa, violência física, violência psicológica ou moral, violência de gênero, violência doméstica, violência familiar, violência patrimonial, violência sexual. Quando surge, a violência, produz consequências amargas perante as pessoas: negligência, abandono, preconceito, medo, sofrimento, dor, estigmatização e afastamentos.

A Organização Mundial de Saúde conceitua a violência como:

O uso intencional de força física ou poder, ameaçado ou real, contra si mesmo, outra pessoa, ou contra um grupo ou comunidade, que resulta ou tem uma alta probabilidade de resultar em lesão, morte, dano psicológico, desdesenvolvimento ou privação (OMS. 2002, p. 05).

Guilherme de Assis Almeida conceitua a violência como sendo “[...] a ação intencional (de um indivíduo ou grupo) que provoca uma modificação prejudicial no estado psicofísico da vítima (pessoa ou grupo de pessoas)" (ALMEIDA, 2001, p. 24). A violência é, por conseguinte, um atentado que viola direitos fundamentais e a integridade do outro sujeito: as vítimas. Afeta seu equilíbrio físico ou moral. Desestabiliza as boas relações com os demais indivíduos, degrada a personalidade pelo esfacelamento de sua autoimagem e valorização íntima. Produz o internamente o sentimento de injustiça e causa revolta. 
A violência, quando ocorre nas estruturas políticas dos governos ou no espaço de convivência da sociedade têm sua causa e motivação no domínio do poder. Violência e poder formam a amálgama que irá forjar a espada utilizada pelo governante, através das policiais e exércitos, e pela deusa da justiça e seus dignitários.

O século XX da humanidade foi, sem dúvida, o século da violência, nas palavras de Hannah Arendt: devido às suas guerras, conflitos e revoluções (1985, p. 01). Foi o período em que se consolidou a aliança entre a ciência e as grandes nações na ingerência de confrontos bélicos transnacionais e globais, além de inúmeros conflitos e convulsões sociais de ordem interna ou regionalizados.

O século XXI não se mostra, porém, muito distante da continuidade da violência como meio de poder. Os conflitos entre pessoas é algo considerável em uma sociedade pluralista e desigual. Todavia, são de maior destaque e repercussão os conflitos entabulados entre indivíduos ou grupo de cidadãos e o Estado enquanto entidade política soberana e detentora do monopólio do uso da força e da violência.

A ideia de violência não é somente um atributo utilizado pelos indivíduos enquanto em sociedade. Embora o conceito básico de violência se encontre adstrito em um agir humano, tal poder de ação se instrumentaliza em atitudes proativas dos seres e se materializa, principalmente, em ações e práticas do poder instituído, ou seja, o Estado enquanto entidade política e institucional se utiliza constantemente da violência como instrumento de alcance de seus desideratos.

"A violência existe e, muitas vezes, nos torna incapazes de compreendê-la, pois ela é o oposto da paz e do bem, seu impacto é devastador, impiedoso e implacável" (SAAD TOSI, 2017, p. 134). A violência não permite o exercício do raciocínio, não permite o exercício da escolha, não permite a liberdade de autodeterminação dos povos (do ponto de vista internacional) ou de capacidade civil e autonomia de vontade (na ordem jurídica intranacional).

Sobre isso nos fala Eduardo Bittar e Guilherme Almeida:

Violência e não violência são qualificadoras do agir humano. Existem duas, não mais, formas de agir. Uma violenta e outra não violenta. Não há caminhos intermediários. Podem variar os graus na escala da violência. No entanto, ela ou está presente, ou não está. [...] A não violência não é uma resistência passiva, mas uma outra forma de agir. A ação não violenta parte de um conhecimento da ação violenta e cria uma alternativa a ela, superando-a. Sabedora de sua existência e ciente de seus males, exercita uma forma de ação negadora da violência. A não violência é também uma 
resposta eficaz contra a violência, tendo em vista a preservação da integridade psicofísica do ser humano (BITTAR, 2012, p. 638).

O filósofo e pensador esloveno Slavoj Zizek fala que a "violência subjetiva" é apenas parte da violência que vemos: conflitos civis e internacionais. Afirma ainda da existência de outras duas formas de violência, ditas como "objetivas" ou quase invisíveis, formando um triunvirato e que seriam: a "violência simbólica" localizada na linguagem e suas formas; e, a "violência sistêmica ou simbólica" resultado dos sistemas econômico e político (ZIZEK, 2014, p. 17). O pensador eslavo adepto do marxismo se contrapõe ao pensamento dominante, modernamente, nas relações internacionais do repúdio à guerra e da ciência política de questionamento da violência como meios ilegítimos.

Pois, ainda para Zizek “[...] estigmatizar a violência, condená-la como 'má', é uma operação ideológica por excelência, uma mistificação que colabora no processo de tornar invisíveis as formas fundamentais da violência social” (ZIZEK, 2014, p. 134). Em sua crítica ao capitalismo afirma que muito pior que as violências subjetivas são as violências simbólicas tidas como normais e não enfrentadas na luta cotidiana e diária.

Considerando então sob o prisma filosófico, “[...] o perigo inerente à nova realidade da humanidade parece consistir no fato de que essa unidade, baseada nos meios técnicos de comunicação e violência, destrói todas as tradições nacionais e enterra as origens autênticas de toda a existência humana" (ARENDT, 2008a, p. 65).

Na visão de Carl von Clausewitz a violência constitui meio cujo fim é impor a sua vontade ao inimigo (1996, p. 08). Para o "filósofo da guerra" o conflito entre os homens depende de dois elementos diferentes: sentimento de hostilidade e a intenção hostil (Id., p. 09). A violência não seria uma medida semelhante à irracionalidade e sim uma opção política quando existentes em um conflito o composto explosivo do sentimento de hostilidade entre as partes; acrescidos da faísca da intenção hostil e com intuito de infringir ao outro a violência.

A violência quando presente em situações de conflito coletivos ou com uma expressiva quantidade de sujeitos apresenta a conotação individual de cada um dos envolvidos pela sua apreensão de como se deu o uso da violência. Bem como produz aquilo que se denomina "experiências coletivas de conflito" (GADEA, 2011, p. 05) e as percepções coletivas desse embate.

Essas experiências coletivas de conflito quando reiteradas e constantes produzem um sentimento de naturalização da violência. Torna-se algo usual, rotineiro, comum. "As experiências coletivas de conflito definem uma situação de violência quando a comunidade já 
nem sequer parece 'falar' mais sobre os que estariam envolvidos nelas" (GADEA, 2011, p. 06). Resultado disso são a insatisfação, a ausência de reações e a normalização da violência, quando não deveria sê-lo.

O conflito é, talvez, inerente à própria vida em sociedade. Ocorrendo o confronto entre indivíduos se apresenta na esfera das relações de vida em sociedade o Estado procura se apresentar como o ente-juiz para resolver o conflito. Quando, porém, apercebe-se um iminente conflito entre as pessoas e o Estado pelo desequilíbrio de avaliações e interesses ocorre que a desconsideração dos anseios sociais é sempre a saída utilizada desde nas democracias abertas até mesmo nos governos autoritários. A mais utilizada forma de resistência sempre foi a da violência, do conflito e do confronto, resultando em guerras civis ou insurgências armadas com inúmeras mortes.

Na opinião de Celso Lafer:

A violência brota da ira, mas a ira não é uma reação automática ao sofrimento e à miséria. Ninguém reage iradamente a um terremoto ou a uma doença incurável. É só quando existem razões para se acreditar que determinadas situações e condições podem ser mudadas, e não o são, é que surge a ira (LAFER, 1988, p. 210).

Jean-Marie Muller se aproxima à opinião de Celso Lafer, porém, declarando ser a violência fruto da agressividade; a violência seria apenas uma expressão da agressividade inerente à natureza humana. (MULLER, 2007, p. 21). Embora racional o ser humano seria instintivo e impulsivo; e, através da violência se manifestaria essa agressividade inata.

A violência nem sempre se apresenta solitária ou isolada. Ela se apropria dos espaços físicos e ocupa a central de comando dos sujeitos envolvidos. O autor ou responsável pela prática da violência não mais exerce livre raciocínio sobre seus atos ou ações. A violência possuía a capacidade de irracionalizar pessoas e situações tornando-as meros reprodutores mecânicos do instituto de destruição subjacente àquele conflito. Produz uma loucura momentânea e uma cegueira incondicional incapazes de impor limites à ação violenta. Da mesma forma, transforma suas vítimas em meros objetos, desumanizando-as.

As situações em que a violência são utilizadas não são um atentado apenas contra aqueles contra a qual foi intentada. Manifesta-se como um risco e uma ameaça aos demais, sujeita a condições não claramente delimitadas. O que impossibilita uma certeza e uma segurança verdadeiras sobre a eventual repetição ou atingimento aos demais sujeitos antes não afetados. 
Todo movimento pacifista que se prega como defensor da paz deve ter por meta sua movimentação política e social sem, contudo, a apologia do uso da violência. Ao contrário, deve ela ser evitada e não integrar quaisquer medidas de prática ou teoria. A apologia à violência não é capaz de produzir verdadeiramente a paz senão quando adjetivada como não violenta. Essa perspectiva se apresenta como uma possibilidade real de prática por todos cidadãos mesmo contra a violência realizada pelo Estado ou seus agentes de segurança e instituições, como veremos.

\section{A violência do Estado ou institucionalizada}

Por que razão rechaçamos as violências praticada pelos indivíduos e grupos enquadrando-as como crimes sujeitos às penalidades mais graves de nosso ordenamento jurídico e não temos a mesma abjeção e clamor por justiça quando a violência é praticada pelo Estado e seus agentes diretos? Por qual motivo percebemos diariamente situações de violência e isto não mais nos abala? Por que vemos nos noticiários o uso cotidiano da violência e não manifestamos qualquer reação?

Max Weber diz, em política como vocação, pertencer ao Estado o monopólio da coerção física legítima. Consigna o pensador alemão: “[...] devemos conceber o Estado contemporâneo como uma comunidade humana que, dentro dos limites de determinado território [...] reivindica o monopólio do uso legítimo da violência física" (WEBER, 2011, p. 39). A violência física e a imposição de ações não desejadas pelo sujeito através da coerção e sustentadas pelo direito penal e pelos órgãos de segurança teriam por objetivo a organização da sociedade e manutenção da ordem.

A violência legítima seria, conseguinte, àquela realizada com a concordância da população e conforme autorizada pelas leis do Estado. A violência pelo Estado seria legal e legítima. Não da mesma forma é tratada as violências que não proveem do Estado, essas consideradas ilegais. Por ser legal e legítima ganha a denominação de coerção. "A ordem pública só pode resultar de uma organização coercitiva da sociedade baseada em obrigações e proibições. O Estado exerce um poder de coerção” (MULLER, 2007, p. 111).

O domínio da violência estatal se justifica na racionalidade da legalidade. Através de uma racionalidade estigmatizante e excludente se procura esconder - perante punições e prisões - justificar ou minimizar a compreensão do problema; pois, aos olhos menos atentos. A ocultação é menos dolorosa perante a sociedade afeta pela violência ou pelo Estado desafiado em sua pretensa superioridade pela ocorrência do ilícito penal. 
Por essa lógica jurídica de crime e castigo, a violência se transforma em objeto assustador dedutível apenas no silogismo culpado ou inocente. Isso quando temos uma pessoa, um sujeito como o autor direto da realização da violência. Mas, nem sempre assim se apresenta.

Muitas vezes a violência possui sim um rosto quando se faz por meio de pessoas físicas. Ocorre que muitas vezes a violência é uma prática realizada por mandato. Uma pessoa, agente público e representante institucional, pratica o tipo violento sob a proteção do Estado e em seu nome. Embora seja realizada por uma pessoa, fá-lo em nome da instituição, da organização política, da pessoa jurídica e do Estado.

Acostumamo-nos e não nos torna mais repugnantes a ação violenta do Estado. Sofremos um processo de paralisia emocional perante as reivindicações que terminam por utilização da violência. Afinal, depois de nossa hipnose social e coletiva passamos a considerar normais toda ação da polícia ou do judiciário que se valha da força e da violência. Sejam contra as manifestações, marchas, passeatas, barricadas, protestos, demonstrações de descontentamento. Mesmo aqueles pacíficos.

Nesta nossa sociedade do entorpecimento - estamos entorpecidos por nossos aparelhos de tecnologia e anestesiados pela nossa conformidade - todo tipo de reação contrária ao Estado passa a ser reprimida, suprimida, exterminada; ainda que necessários meios violentos. Toda ação se justifica se tiver por fim a manutenção da ordem e da paz social, dizem as autoridades. Por essa razão nossos parâmetros de violência, sofrem uma descalibração social, e consideramos como normal a prática da violência estatal. Repudiamos a violência privada, porém, aplaudimos e justificamos a violência pública.

Nossos parâmetros de obediência à lei e ao Estado coloca como inimigo toda aquele que infringiu a lei; logo, deve ser processo, condenado, punido. Dessa forma temos a sensação íntima (ou seria ilusória?) de justiça. Todavia, a violência estatal e de seus representantes é vangloriada e permitida a partir de excludentes normativas de antijuridicidade como a legítima defesa, o estrito cumprimento de dever legal e o estado de necessidade; logo, possibilitadoras de julgamento e de processamento, mas sem a punição estatal para tanto. Afinal, para que o Estado reconheceria seus erros e excessos? Viva a violência estatal, pois, o Estado atua pro societatis. Aqui reside nossa ironia, crítica e questionamento:

O maior risco das discussões sobre a questão da violência é a de legitimarmos a sua atuação dentro de um campo específico de 
reconhecimento, onde dela se utilizaria em suas formas e sob seus fundamentos, pois se encontraria permitido para alcançar o fim antevisto e esperado (VIEIRA, 2012, p. 04).

A violência passa a ser instrumentalizada como agir do Estado. Ao aceitarmos essa condição e sua repetição na cena cotidiana de nossos e na teia da vida de nossa sociedade assumimos o risco de considerar normal acontecimentos que nos deveriam causar ojeriza e reprovação. Costumamos nos revoltar ou nos indignar tão somente quando a violência passa a atingir a nós diretamente ou pessoas do nosso círculo de convivência ou das nossas relações familiares e profissionais. Excluindo-se essas hipóteses geradoras da revolta e da inconformidade passamos à condição de meros espectadores passivos e silentes aos reclames dos oprimidos e violentados.

Para Hannah Arendt (1970, p. 51) “[...] se os objetivos não forem alcançados rapidamente, o resultado será não meramente a derrota, mas a introdução da prática da violência em todo o organismo político". O pensamento arendtiano sobre a violência procura deixar claro as diferenças entre violência e poder. A violência seria um meio (instrumentalização da violência), e não um fim.

Então a partir do momento em que se realizasse o transplante para a legitimação da política das ferramentas da violência, sua prática como toda ação, teria o potencial de transformação do mundo, mas a transformação mais provável seria para um mundo mais violento, mais cruel, mais injusto. A violência - com sua meia irmã, a guerra - é a contradição da razão e desmancha toda a construção política, jurídica, econômica e social ao longo da história humana. Nas palavras de Adorno, “[...] o Estado é uma empresa de dominação de uns sobre outros, por meio do recurso à violência ou à ameaça de seu emprego. No entanto, trata-se de uma violência legítima, porque autorizada pelo direito" (ADORNO, 2002, p. 06).

Como tivemos possibilidade de discorrer, quando de nossos estudos no mestrado:

Mesmo possuindo o benefício do uso da violência, circunscrito a critérios de legalidade, outorgar tal arma na mão do Estado se torna de extremo risco à coletividade de sujeitos. A norma jurídica como caráter limitativo da injunção dos instrumentos de poder na vida do indivíduo se mostra extremamente fraca, insuficiente, posto que se apresenta manobra facilmente manipulável ao critério de exigência e interesse do soberano, principalmente se concomitante às manobras de manipulação das massas e dos instrumentos de legitimação do poder. Qual seria então a esfera maior de proteção do indivíduo e da sociedade frente à violência a ser exercida pelo Estado, se nem mesmo a regra jurídica positivada se mostra incapaz de garantir os direitos contra o arbítrio da força? Esse papel, em vez de ser exercido pela 
lei é primeiramente garantido pelo reconhecimento de direitos fundamentais das pessoas e dos grupos sociais (VIEIRA, 2012, p. 05).

Todo tipo e forma de violência devem ser rejeitados. Não podemos mais tolerar prática da violência como algo rotineiro: seja conosco, seja com os desconhecidos. A violência cria uma dualidade em que os não atingidos por ela devem ser adeptos de suas justificativas e razões; os demais, as vítimas e àqueles que sofreram de sua força destrutiva e desumana são colocados em lado contrário. São, portanto, o oposto. Aqueles que devem ser combatidos. Conforme Jean-Marie Muller: “A violência irrompe tão logo o homem deseja o ilimitado e vê seu desejo contrariado por outros" (MULLER, 2007, p. 29).

Como aluno e discípulo do pensamento arendtiano, Celso Lafer, esclarece:

A violência destrói o poder, mas não o cria ou substitui, pois o poder, para ser gerado, exige a convivência, e a violência se baseia na exclusão da interação / cooperação com os outros. Isto explica a combinação, que não é rara na experiência política, de violência e impotência, pois governantes e governados frequentemente não resistem à tentação de substituir o poder que está desaparecendo pela violência (LAFER, 1988, p. 209-210).

O poder é inerente à sociedade civil e ao Estado nos regimes democráticos. Porém, a violência se mostra como ferramenta de manutenção ou sustentação desse poder. Quanto mais fraco se torna as relações de poder e legitimidade na sociedade mais o governante necessita da violência como ferramenta de manutenção do seu poder e de seus interesses. E não dos interesses do povo.

Essa aparência de naturalidade da violência faz com que surja a mais a mais profunda e estrutural de suas formas: a "violência simbólica" e com sua naturalização de sus objetos e seus alvos configuraria o "permanente estado de violência" (MENDONÇA, 1996, p. 94). O Estado toma para si, portanto, a tarefa de punição e de imposição do uso da força mesmo que para isso precise da violência: física ou simbólica.

A violência física afeta diretamente o corpo do sujeito. Seu estado físico é afetado pela restrição de liberdade ou pelas demais formas de punição e sevícia. Essa é monopólio do Estado e se revela nas práticas mais corriqueiras. Quando alguém afeta a integridade física de outrem pode vir a responder pelo crime de lesão corporal como previsto no Código Penal. Quando, porém, o Estado se utiliza de seus atributos de legalidade para realizar a violência física a não ser que haja excessos e circunstâncias teratológicas a violência física empreendida contra o ser humano será considerada como estritamente necessária. 
A violência simbólica é aquela violência que não atinge os corpos, ou seja, a violência física e sim aquela que ataca o psicológico e a moral da pessoa. Esse termo cunhado pelo sociólogo francês Pierre Bourdieu que assim a define: "A violência simbólica é uma violência que se exerce com a cumplicidade tácita daqueles que a sofrem e, frequentemente, daqueles que a exercem na medida em que uns e outros são inconscientes de a exercer ou a sofrer" (BOURDIEU apud SANTOS, 2015, p. 184). Enquanto o pensamento weberiano considera a violência como monopólio legítimo do Estado, a concepção de Bourdieu trata de acrescer a utilização pelo Estado tanto da violência física como da violência simbólica.

A violência exercida pelo Estado e sob o atributo da legalidade se utiliza ainda do fenômeno da força para sua execução. Nada obstante ser a violência por si só um atributo de conformação do outro à vontade é através da força e do condão da coerção que a violência se tornará uma importante arma nas mãos do Estado. Em situações em que a legalidade ou a discricionariedade administrativa entender cabíveis, a seu juízo político e de soberano, a força e a violência integrarão as ações do ente estatal e de seus mandatários.

Nas lições de Bobbio:

Quando em tais contextos se fala de força, entende-se o uso de meios capazes de infligir sofrimentos físicos, e portanto neles não estão incluídas nem a violência psicológica, ou seja, o uso de meios de manipulação da vontade alheia com objetivo de obter os efeitos desejados, nem a violência institucional ou estrutural, ou seja, a violência que deriva da relação de domínio no interior de certas instituições totais [...]. É chamada de força a violência, também física, que é usada por aquele que está autorizado a usá-la por um sistema normativo que distingue, com base em regras eficazes, o uso lícito e o uso ilícito dos meios que infringem sofrimentos e também, em casos extremos, a morte [...]. (BOBBIO, 2000, p. 515).

Ao Estado cabe o monopólio da violência dita legítima e institucionalizada. É de sua tarefa também a repreensão e o combate a qualquer outra forma de violência que não provinda do Estado e de seus instrumentos de controle. Já a violência externa ao Estado, ou interestatal, transcende qualquer soberania (MEI, 2013, p. 39). Assim, no âmbito interno somente a violência realizada pelo próprio Estado ou seus representantes é permitida. $\mathrm{Na}$ sociedade internacional, todavia, embora reprimida ou rejeita a guerra se mostra uma realidade inseparável das relações entre as nações. Logo, a violência serve de meio e instrumento para utilização no espaço doméstico ou interno quanto na vivência internacional.

A violência acrescida da força se transforma em um instrumento de imposição do Estado à legalidade e a vontade dos detentores do poder. Machado Paupério, nesse interim, afirma: "No fundo, a ordem jurídica e a ordem estatal são absolutamente idênticas, 
identificando-se por isso a ordem jurídica e a própria ordem da força” (PAUPÉRIO, 1981, p. 05). O sistema penal e anteriormente a esta o sistema policial e de controle exercem a tarefa primordial de exercício da força e da violência praticadas pelo Estado.

Conforme reafirma Jean-Marie Muller:

Uma das funções reivindicadas pelo Estado, em nome da legítima defesa dos cidadãos, é deter, julgar e condenar aqueles que desobedeceram à lei e perturbaram a ordem pública. Mas, ao mesmo tempo, o Estado reivindica o direito de recorrer, ele próprio, à violência para punir a violência (MULLER, 2007, p. 117).

Em continuidade à sua lógica de explicação da violência estatal como um sistema de auto justificação e de auto-regulamentação nos explica o filósofo francês:

Ao institucionalizar a violência como um meio normal - que serve de norma - e regular - que serve de regra - na gestão dos inevitáveis conflitos que surgem na sociedade, o Estado lhe concede o direito de cidadania. Portanto, é o conjunto das relações sociais que se encontra contaminado pela lógica da violência. Na democracia, o objetivo principal da política é colocar a violência à margem da lei; no entanto, o Estado contraria esse objetivo ao instalar a violência dentro da esfera da lei (MULLER, 2007, p. 121).

Se o Estado detém sob seu controle o monopólio do uso da força e da legalidade de imposição da violência física e simbólica como construir limites ou barreiras institucionais à ação desse Estado? Mesmo quando fundamentado e justificado no primado da legalidade pode ocorrer situações de extremismos que põe em risco não somente a vida ou demais direitos dos sujeitos atingidos, mas também a própria democracia ou a convivência social.

Se o Estado concentra em seus órgãos de atuação - Executivo, Legislativo e Judiciário - os meios e as condições para o exercício irrestrito da força e da violência como evitar suas transbordamento além dos contornos jurídicos da legalidade? Ou mesmo como questioná-los quanto à legitimidade dessa legalidade, afinal, a legalidade tem relação direta com a norma jurídica provinda do Estado e que, teoricamente, representa as aspirações sociais sob o primado da democracia.

O magistério de Machado Paupério reafirma: "Toda autêntica concentração de poder, seja ela de natureza política, militar ou econômica, põe em perigo a existência do direito" (PAUPÉRIO, 1981, p. 05). Se o princípio basilar da democracia figura que todo poder emana do povo - preceito repetido no parágrafo único do primeiro artigo da Constituição da República Federativa do Brasil - então é de se cogitar a possibilidade de uma 
ação do mesmo povo contrária às leis e ao seu Estado e governo, caso não concordassem com os fundamentos estatais.

Mesmo sob o risco de enfrentar diretamente as punições e o poder coercitivo do Estado quando no desrespeito à legalidade os cidadãos teriam como última ratio seus direitos e sua liberdade. Inclusive com as condições e meios para a defesa de seus direitos e prerrogativas. Logo, “[...] a liberdade exige instituições jurídicas e políticas apropriadas, inclusive um judiciário independente e uma universidade livre, que não são produto da violência" (ARENDT, 2008b, p. 209).

Mas, e quando os poderes e órgãos estatais não apresentam respostas aos reclames sociais nada mais resta aos cidadãos senão a conformação à violência do Estado? Entendemos que não. Quando a lesão ou ameaça não encontrar ressonância nas instituições políticas e jurídicas devem sê-lo na ação social.

Os limites então possíveis a restringir a ação do Estado no uso da força e da violência seriam, portanto, no plano teórico os direitos humanos e fundamentais; e, no plano prático ou da ação os movimentos políticos do direito de resistência e da desobediência civil. Estes também direitos como veremos no prosseguimento do trabalho.

\section{Existe alternativa à violência?}

A violência tomada no âmbito do poder de repressão pelos órgãos de segurança e pelo poder de punir do Estado apresentam uma problemática questão sob o ponto de vista jurídico e da política mesmo especialmente quando se trata da proteção aos direitos humanos ou direitos fundamentais.

Por essa monta, considerar a violência como proibição somente, não resolve relações complexas que envolvem o mundo do agir, derivados historicamente da religião, do poder ou da sociedade. A violência não é somente praticada por aqueles que infringem os deveres jurídicos e realizam a prática de algum tipo penal incriminador que atenta contra a liberdade, a integridade física ou a dignidade de outrem. Muitos a utilizam sob o pretexto de manutenção da ordem ou da regularidade das relações sob uma pretensa paz social.

Argumentar no sentido do uso da violência como uma forma legal de fazer valer a vontade do soberano e dos aparelhos estatais de controle desconsidera toda construção histórica de humanização dos seres em conflito ou vítimas de abusos da força. Como equilibrar no senso de legalidade e justiça o uso da violência e a manutenção dos direitos fundamentais e suas garantias se esgarçar a norma hipotética e atingir o corpo ou a moral daqueles que sofrem justamente pela instrumentalização da violência. 
No pensamento de Jean-Marie Muller a violência é o abuso da força; mais ainda, a violência por si só é um abuso e o recurso à violência igualmente se mostra um abuso (MULLER, 2007, p. 31). Irrompendo contra esses abusos e contra esse mal que se concebe a não violência como uma alternativa legítima, menos agressiva, mais pacífica e em consonância com os direitos humanos.

As ações não-violentas se mostram como ferramentas legítimas e eficientes para enfrentar desde ditadores e governos déspostas ou tirânicos (SHARP, 2010). Até mesmo para o enfrentamento daqueles Estados ditos democráticos e centrados no primado da legalidade e do Direito. Tais ações ou propostas são instrumentalizáveis em lutas e conflitos internos ou mesmo diante de ingerências bélicas e confrontos armados entre nações na esfera internacional.

[...] quando pensamos em teóricos do não-violência, a imagem de Gandhi vem à mente, tais Lev (ou Leo) Tolstoy ou Martin Luther King. Estes três personagens, com sua fama internacional cada um para razões diferentes, ter completamente eclipsado outros muitos teóricos da não-violência mais importante, como Bart de Ligt, Jean Marie Muller ou Gene Sharp (que é considerado como o autor político vivo com mais seguidores no mundo). (PEREZ, 2010, p. 11, tradução nossa).

Para compreender os tipos de não-violência precisamos antes entender o que é exatamente não-violência. Guilherme de Assis conceitua não violência como “[...] ação intencional que provoca modificação prejudicial na pessoa ou no grupo de pessoas destinatários da ação" (ALMEIDA, 2001, p. 25).

Castañar Perez afirma que casos como os de Tolstói, Gandhi e Luther King partiam de uma concepção de não violência denominada holística, pois, baseava-se em um princípio necessário para todos os aspectos da vida, uma filosofia moral válida para todas as circunstâncias (PEREZ, 2010, p. 11). O mesmo autor, porém, destila suas críticas a esses personagens, por levarem a entender a não-violência como um conceito moral e pessoal mais do que um conceito político. Neste ponto reside um dos diferenciais por qual pretendemos analisar os conceitos de pacifismo e não-violência de Gene Sharp, na construção de uma teoria da ação não-violenta como uma doutrina política e não simplesmente moral ou teológica.

Então as pessoas com menos pretensões de perfeição moral do que legitimamente luta para superar alguma situação que eles consideram ser injustiça e pode rejeitar ação política não violenta com base em um préjulgamento ignorante, por conhecer as abordagens políticas para esta forma 
de ação baseada em estereótipos, porque muitas vezes a imagem desses líderes da não-violência está ligado a um pacifismo calmista muito longe de suas verdadeiras abordagens revolucionárias, desconfortável ao poder. (PEREZ, 2010, p. 12, tradução nossa)

A palavra não-violência dessa forma como escrita é tradução do termo "nonviolence" que fora utilizado por Gandhi e Tolstói. Sua utilização segue uma corrente ética de pensamento em que a não violência integra os atributos morais de cada pessoa. Gene Sharp, como representante de uma corrente conhecida como pragmática e com a intenção de trazer o conceito de não violência para o território da política escolheu o termo nãoviolência, ou seja, do inglês "nonviolence" para identificar sua proposta da doutrina não-violenta nos domínios da ação política.

Ora, inegavelmente a relação entre poder e violência se faz presente nos dias atuais. Neste sentido as palavras de Hannah Arendt:

Mencionei a relutância generalizada em se tomar à violência por si mesma como um fenômeno, e devo agora qualificar essa afirmação. Se nos voltarmos para os debates sobre o fenômeno do poder, descobriremos logo que existe um consenso entre os teóricos políticos da esquerda e da direita de que a violência nada mais é do que a mais flagrante manifestação de poder (ARENDT, 1985, p. 22).

Sendo o Estado o ente ou entidade jurídica mais poderosa de toda a sociedade não há como se negar a utilização desta para a feitura de seus objetivos. Ocorre que, independentemente de o Estado estar centrado politicamente em um regime de tirania ou ditatória ou ter por substrato uma aparente democracia popular com previsão de direitos fundamentais quando os poderes políticos ou das pessoas que controlam o Estado se unem criminosamente para exercer a opressão irremediável, qual a saída? A quem recorrer? É quando o chamado direito de insurreição aparece.

Para Guilherme de Assis Almeida a não-violência representa, pois, um princípio de Direito: ao qual fundamenta o novo Direito Internacional dos Direitos Humanos no período pós-guerra e é deduzido de seu sistema normativo. Desse modo nos diz seu magistério:

[...] a não violência funciona como princípio normativo do DIDH, pois ela orienta a forma de ser dessas normas de conduta, que não podem fazer uso, de modo algum, de métodos violentos, tais como a tortura e a guerra. Sua função como princípio de orientação e diretivo do DIDH será de indicar diretrizes para a criação desse 'novo' sistema de direito (ALMEIDA, 2001, p. 52). 
A Organização das nações Unidas para a Educação, Ciência e Cultura (UNESCO) lançou o "Manifesto 2000 por uma Cultura de Paz e Não-Violência". Assinado por diversos ganhadores do Prêmio Nobel da Paz traz uma convocação para a construção de uma cultura de paz. Tem como premissas: (1) respeitar a vida; (2) rejeitar a violência; (3) ser generoso; (4) ouvir para compreender; (5) preservar o planeta; (6) redescobrir a solidariedade.

A chamada "Primavera Árabe" se identificou como um movimento de inúmeros países do Oriente Médio consistentes em greves, manifestações e enfrentamentos, visando à derrubada do governante, em sua maioria estendo no poder há décadas sem qualquer reconhecimento democrático.

No Brasil as manifestações de junho e julho do ano de 2013 ressurgiram como um acontecimento social notável. Começaram como reuniões de grupos não conformados com o aumento do preço do transporte público e avançaram para passeatas de milhares de pessoas e $\mathrm{m}$ diversos locais do país cujas bandeiras envolviam os mais diversos assuntos. Entretanto, a característica marcante e traço principal destas manifestações foram, em sua maioria, o confronto e a resistência sem grandes violências. Exceção feitas a determinados grupos de pessoas que se utilizam dessas manifestações como forma dissimulada de praticar vandalismos e destruição de patrimônio alheio.

A não-violência surge, com os exemplos do século $\mathrm{XX}$, como uma doutrina política da alteridade. Não tem por objetivo a tomada do poder, a modificação de sistemas econômicos ou revolução. Ela tem o respeito ao próximo como limites de atuação ao proclamar a rejeição da violência como solução e caminho. Mesmo perante situações de flagrante desrespeito aos direitos fundamentais da pessoa a não violência procura demonstrar o erro do agente causador do sofrimento. Questiona a legitimidade e a injustiça de medidas que desagradam o povo, especialmente àquelas que redundam na coisificação e violentação do ser humano.

Dentro do nível sociopolítico se encontra a perspectiva em que a não violência se entende como uma forma de ação política, cujos teóricos e práticos poder haver chegado a optar por ela igualmente por proceder a uma filosofia não violenta, ou por considerar que é a forma mais adequada de resolver o conflito em que se desenvolve seu contexto ou simplesmente por considerá-la mais efetiva, muitas vezes devido tão só a que a grande assimetria de forças torna a luta ineficaz (PEREZ, 2010, p. 27). 
Respondendo ao nosso questionamento proposto no início dessa seção sobre a existência de alternativa à violência concluímos ser a não-violência uma das soluções possíveis e sócio-juridicamente viáveis para o enfrentamento dos problemas apresentados nas presentes democracias constitucionalistas. Logo, a não-violência ainda que não expressa no ordenamento jurídico interno ou na Carta Constitucional como um direito fundamental, de natureza individual e coletiva, representa inexoravelmente um preceito fundamental de cidadania e de democracia. Exercível, portanto, nos planos teóricos e na prática do cotidiano: perfeitamente factível e adequada às nossas sociedades presentes.

\section{Considerações finais}

A violência é um atentado que viola direitos fundamentais e a integridade dos outros sujeitos. A violência, contudo, quando ocorre nas estruturas políticas dos governos ou no espaço de convivência da sociedade têm sua causa e motivação no domínio do poder: o monopólio do uso da força e da violência pelo Estado.

O Estado então sustenta em si o monopólio da coerção física legítima. Leis do Estado. A violência pelo Estado seria considerada legal e legítima: porque previstas em leis derivadas da vontade popular. Denomina-se, por conseguinte de coerção. Inversamente, quando as violências que não proveem do Estado são consideradas ilegais. Socialmente se rejeita a violência privada, porém, aplaude-se e se exalta a violência pública: a violência institucional.

A violência praticada pelo Estado passa por um processo de naturalização e normalização. A violência estatal e de seus representantes passa a ser aceita e reconhecida, nem ao menos questionada ou criticada. A violência passa a ser instrumentalizada como agir do Estado. O Estado toma para si, portanto, a tarefa de punição e de imposição do uso da força mesmo que para isso precise da violência: física ou simbólica.

Mesmo sendo o poder inerente à sociedade civil e ao Estado nos regimes democráticos a violência se mostra como ferramenta de manutenção ou sustentação desse poder. Ao Estado cabe o monopólio da violência dita legítima e institucionalizada. Passa para a responsabilidade estatal também a repreensão e o combate a qualquer outra forma de violência que não provinda do Estado e de seus instrumentos de controle. A violência estatal como demonstração de seu poder reside no domínio da força. A violência acrescida da força se transforma em um instrumento de imposição do Estado à legalidade e a vontade dos detentores do poder. Sua manipulação e restringimento então se faz por meio de sanções e da 
coerção, da criminalização e da pena. Portanto, direito e coerção estão sob os controles do Estado; assim como a violência.

A não-violência surge então como uma proposta ao caminho da violência do Estado. A construção da palavra não-violência teria sua origem na escrita indiana da ahimsa, ou seja, a negação da violência. Ahimsa seria a não violência ou prática sem o uso da força, do ódio da violência. A não-violência como uma proposta política não seria apenas a não realização da violência e do dano. Esse seria o conceito negativo de não-violência. Não é, porém, uma técnica passiva.

Não-violência é um conceito ativo e positivo que envolve não só não praticar a violência como também a busca e organização de outras técnicas que não se valham ou utilizem da violência. A não-violência não se restringe à negação da violência, mas a busca de suas alternativas e substituições. A missão da não-violência é realizar uma transformação dos conflitos antes restritos à violência.

Portanto, a não-violência representa um preceito jurídico fundamental e de potencial transformador das sociedades jurídico-políticas da contemporaneidade, pois, são capazes verdadeiramente de promover mudanças de fundo na sociedade e nas pessoas.

\section{Referências}

ADORNO, Sérgio. Monopólio estatal da violência na sociedade brasileira contemporânea. In Miceli, Sérgio (org) O que ler na Ciência Social brasileira (1970-2002). São Paulo: Sumaré/Anpocs, 2002, Volume 4.

ALMEIDA, Guilherme Assis de. Direitos Humanos e Não-violência. São Paulo: Editora Atlas, 2001.

ARENDT, Hannah. Da Violência. Brasília: UnB, 1985.

ARENDT, Hannah. Homens em Tempos Sombrios. Tradução: Denise Bottmann. São Paulo: Companhia das Letras, 2008a.

ARENDT, Hannah. O que resta de Auschwitz. São Paulo: Biotempo Editorial, 2008b.

BITTAR, Eduardo Carlos Bianca; ALMEIDA, Guilherme de Assis. Curso de Filosofia do Direito. São Paulo: Atlas, 2012.

GADEA, Carlos A. A Violência e as Experiências Coletivas de Conflito. In: Revista Crítica de Ciências Sociais. Coimbra, n. 92, março/2011, p. 75-98.

HARI, Johann. Na Fissura: Uma História do Fracasso no Combate às Drogas. Tradução: Hermano Brandes de Freiras. São Paulo: Companhia das Letras, 2018. 
HOBSBAWM, Eric. A Era dos Extremos: O breve século XX. Tradução: Marcos Santarrita. 02 ed. São Paulo: Companhia das Letras, 1995.

LAFER, Celso. Paz e Guerra no Terceiro Milênio: Os ideais de Bobbio, balanço e perspectivas. In: TOSI, Giusepe (Org.). Norberto Bobbio: Democracia, Direitos Humanos, Guerra e Paz. João Pessoa, Edita da UFPB, 2013.

LOSURDO, Domenico. A Não Violência: Uma história fora do mito. Rio de Janeiro: Revan, 2012.

MEI, Eduardo. Estado, Guerra e Violência: As "Novas Guerras" e suas Implicações para a Teoria Clausewitziana da Guerra. In: SAINT-PIERRE, Hector Luis (Org.). Paz e Guerra: Defesa e segurança entre as nações. São Paulo: Editora Unesp, 2013.

MENDONÇA, Sônia Regina de. Estado, Violência Simbólica e Metaforização da Cidadania. In: Revista Tempo. Rio de Janeiro: v. 1, 1996, p. 94-125.

MULLER, Jean-Marie. O Princípio da Não-Violência: Uma trajetória filosófica. Tradução: Inês Polegato. São Paulo: Palas Athena, 2007.

OMS. World report on violence and health. Geneva, World Health Organization, 2002.

PAUPÉRIO, Arthur Machado. O Direito Político de Resistência. Rio de Janeiro: Forense, 1962.

PÉREZ, Jesús Castañar. Breve História de La Acción Noviolenta. Madrid: Ediciones Pentapé, 2010.

SAAD TOSI, Lamia Jorge. A Banalização da Violência e o Pensamento de Hannah Arendt: Um debate ou um combate? In: Revista do Laboratório de Estudos da Violência da UNESP. Marília, edição 09, p. 131-159, maio. 2013, p. 84-94.

SANTOS, José Vicente Tavares dos. A violência simbólica: o Estado e as práticas sociais. In: Revista Crítica de Ciências Sociais. Coimbra, n. 108, dezembro/2015, p. 183-190.

SHARP, Gene. Da Ditadura à Democracia: Uma estrutura conceitual para a libertação. 04 ed. Trad. José A. S. Filardo. São Paulo: Palas Athena, 2010.

VIEIRA, André Luiz Valim. Violência, Direitos Humanos e Genocídio. Revista do Laboratório de Estudos da Violência da UNESP. Marília: n. 09, p. 01-11, maio/2012, p. 84-94.

WEBER, Max. Ciência e Política: Duas vocações. Tradução: Leonidas Hegenberg e Octany Silveira da Mota. 18 ed. São Paulo: Cultrix, 2011.

ZIZEK, Slavoj. Violência: seis reflexões laterais. Tradução: Miguel Serras Pereira. São Paulo: Boitempo, 2014. 
Data de recebimento: 12.03 .2020

Data de aprovação: 20.07.2020 